MATEC Web of Conferences 9, 02008 (2013)

DOI: $10.1051 /$ matecconf/20130902008

(C) Owned by the authors, published by EDP Sciences, 2013

\title{
Fire safety of etics with EPS material properties and relevance for fire safety during transport, construction and under end use conditions in external thermal insulation component systems
}

\author{
Edith Antonatus \\ BASF SE, G-PMFIEA - D219, 67056 Ludwigshafen, Germany
}

\section{INTRODUCTION}

EPS is a combustible product, which is often used in ETICS (External Thermal Insulation Component Systems). EPS can be non flame retarded (classified F according to the European classification system) and flame retarded (FR). This paper is going to explain, what the specific properties of EPS in case of a fire are, what the influence of these properties on fire safety is during construction and in end-use conditions, and how testing and classification of EPS alone and within the system is done. In addition to standard tests a number of tests related to the construction situation have been performed and will be presented.

\section{REACTION TO FIRE OF EPS}

\section{Properties, testing and classification}

EPS without flame retardants does not pass any relevant fire tests for construction products and is classified Euroclass F according to EN 13501-1. This type of product may be safely used behind a thermal screen (like gypsum plasterboard), but in many countries even for this type of application Euroclass F products are not allowed.

However for construction purposes in most countries flame retarded (FR) EPS is used. Flame retarded EPS in a number of European countries in the past used to be classified in the best class for combustible products. In Germany the classification was B1 according to DIN 4102 and in France class M1 could be achieved.

With the European classification system the SBI test (EN 13823) was introduced, which is not per se suitable for distinguishing between different types of flame retardant EPS. Reasons are:

- The test has been designed for surface products within a room, while EPS in most cases (as in ETICS) is applied behind protective layers, not as a surface product. This is why in the product standards for EPS (EN 13163), as well as in the standards for other insulation products an annex has been added, which allows for classification in end-use conditions in addition to the classification of the insulation product alone. An example is the test of EPS behind a gypsum plaster board - a situation which represents the application as insulation products inside a building. For this application the end-use classification for all EPS thicknesses can be up to class B.

- The leading parameter for classification with the SBI is FIGRA (Fire Growth RAte) which shows how fast the heat release from the tested product develops. As the product is subjected to a quite large flame in the corner of the test rig, and EPS foam is a thermoplastic product, the flame will

This is an Open Access article distributed under the terms of the Creative Commons Attribution License 2.0, which permits unrestricted use, distribution, and reproduction in any medium, provided the original work is properly cited. 


\section{MATEC Web of Conferences}

consume in the initial phase of the test almost the complete amount of the tested EPS-product in the area of flame impingement, even if no significant flame spread happens. This means that with increasing thickness and density of the tested PS foam product more material is consumed by the burner flame at the beginning of the test - more energy is released because of the increasing amount of material burnt - the FIGRA value gets worse. Flame retarded EPS products boards with a high thickness (for example tested at a thickness of $200 \mathrm{~mm}$ with a density as it is used in façade systems) cannot reach an SBI classifications because they will not even be able to reach results below the limit values for the classification D (FIGRA $\leq 750 \mathrm{~W} / \mathrm{s}$ ), while EPS boards made from the identical material with a very low amount of mass/area (like ceiling tiles made of EPS in a thickness of $10 \mathrm{~mm}$ ) can reach even class B (FIGRA $<120 \mathrm{~W} / \mathrm{s})$. This means, that for a flame retarded EPS product, depending from the thickness and density different classes will be achieved. CE marking on this basis would be difficult, as normally blocks are produced, and then cut into boards with different thicknesses, and for each thickness a different Euroclass would have to be given.

These are the reasons why EPS boards for CE marking purposes normally only are tested in the small burner test, according to EN 11925-2. In this test a clear differentiation between flame retarded and non flame retarded EPS foam is possible. A non FR foam would burn totally in this test, while a FR foam can meet the criteria for class $\mathrm{E}$ (flame height $\leq 150 \mathrm{~mm}$ above point of flame impingement). So flame retarded EPS, which in the past had very good national classifications (B1, M1) is now classified as class E according to EN 13501-1 without a change of the product itself. This applies as well for white, as for grey EPS - both types are treated with the same flame retardant additive and show similar reaction to fire.

\section{Additional control of reaction to fire of flame retarded EPS products}

In addition for example France is using a special system for determining the material properties of EPS and XPS for façade insulation applications, in order to make sure, that the quality defined for the old national safety level will be maintained after introduction of the European classifications.

A certification scheme for EPS and XPS, used for external insulation systems in buildings in France has been introduced in addition to CE marking. The basis is the fact, that different EPS foam products can be compared in the SBI test, if always the same thickness of the product is tested. To develop this scheme a number of EPS products, which used to pass the old national B1 (Germany) and M1 (France) tests where tested in the SBI, and in the small burner. As a result of this testing program it was decided, that the EPS products to be certified, have to be tested in the SBI at a thickness of $60 \mathrm{~mm}$ and in the maximum density to be certified, and have to pass the FIGRA criterion for the European classification D (FIGRA $\leq 750 \mathrm{~W} / \mathrm{s}$ ). Continuous factory production control for the raw material is done with the small burner test according to EN ISO 11925-2, using surface flame impingement and a stricter flame height limitation than that required for class E. So the European tests are used in France, to control a reaction to fire behaviour equivalent to the former class M1.

\section{REACTION TO FIRE TESTING OF FAÇADE INSULATION SYSTEMS IN LABORATORY TESTS}

\section{Testing and classification of façade systems}

In addition to the reaction to fire classification of the EPS boards, laboratory tests of complete façade insulation systems are performed and used for classifying the reaction to fire of the complete system. This has been done in some countries in the past with the old national tests (like in Germany, where more than 50 years of experience with ETICS and other insulation systems are available). 
In Europe a comprehensive system for testing of external thermal insulation component systems (ETICS) has been developed in EOTA (European Organisation for Technical Approvals - now European Organisation for Technical Assessment), which is described in ETAG 004 [1]. It will also be applied (with minor changes) in the harmonized European standard for ETICS which is currently under development in CEN TC 88.

The minimum requirement for every ETICS which shall be classified $\mathrm{E}$ or better is that the insulation product used passes class E. In addition to testing the single components the complete ETICS is subjected to the small burner test (EN ISO 11925-2) and for higher classifications to the SBI test. So systems with combustible components can be classified up to class B, even if some of the components fall into lower classes but are better than F. For non-combustible systems all components have to be non-combustible.

For curtain wall façades (ventilated façades) a similar approach can be taken. Also here classifications for the single components as well as for the complete built-up system can be done. In some countries additional rules have been developed for ventilated façades.

\section{FULL SCALE TESTS}

Since many years it has been acknowledged, that the performance of façade cladding systems in case of a fire cannot be fully assessed by laboratory tests. While the reaction to fire of the components used, can be tested and classified in laboratory tests, for façade cladding systems applied on the outside of a wall, parameters like mechanical performance (stability, falling of parts, melting) and fire spread in voids can only be assessed by using larger scale tests with realistic façade constructions. Here not only the reaction to fire of the components is important, but other details, like quality of fixings, fire barriers etc. are relevant for the performance in reality.

\section{Fire scenarios}

Different types and places of an initial fire may lead to a situation, where flames are impinging on a façade cladding/insulation system:

- A fire from an adjacent building may lead to radiation and burning brands which attack the outer wall of a building. The fire load in this case normally is low.

- A more severe scenario is a fire directly next to the wall of a building, caused for example by a burning waste container or a burning vehicle near the building. In this case the fire load may be severe. Many different scenarios can be assumed here and further analysis is needed, which scenarios are relevant.

- One of the most frequent and also severe cases is a fire leaking out of a window after flashover inside a room in a building. In this case the windows of this room will break; flames will burst out and impact the outer façade with a severe fire load. Even without a relevant contribution of the outer façade covering, such fires spread upwards. Normally the flames from the floor where the fire started will reach the next window above, the window will break and ignition of the room interior in the next floor will take place. Then after some time the process will be repeated and the flames will spread further upwards.

Even if fire spread upwards can happen without any contribution of the outer façade cladding, the performance of the outer wall is important for safety because it is important that

- No fast fire spread happens on the outer side or within the cladding and insulation system.

- No burning parts fall down and endanger fire brigades and persons trying to escape.

This is the reason why full scale tests are done and legislation based on full scale assessment is in place in many countries. 
MATEC Web of Conferences

Table 1. Examples for full scale tests used in different countries.

\begin{tabular}{|c|c|c|c|c|c|c|c|c|}
\hline Germany & Hungary & Poland & UK & Austria & France & Sweden & USA & $\begin{array}{l}\text { ISO } \\
13785-2\end{array}$ \\
\hline $\begin{array}{l}\text { DIN } \\
4102-20 \\
\text { draft }\end{array}$ & $\begin{array}{l}\text { MSZ } \\
14800 \\
\text { part } 6\end{array}$ & $\begin{array}{l}\text { PN- } \\
\text { 90/B- } \\
02867\end{array}$ & BS 8414 & $\begin{array}{l}\text { Önorm B } \\
3800-5\end{array}$ & $\begin{array}{l}\text { Arrêté } \\
10 / 09 / 1970\end{array}$ & $\begin{array}{|ll|}\text { SP } & \text { Fire } \\
105 & \end{array}$ & $\begin{array}{l}\text { NFPA } \\
285\end{array}$ & $\begin{array}{l}\text { Large } \\
\text { scale test }\end{array}$ \\
\hline \multicolumn{9}{|c|}{ Exposure } \\
\hline $\begin{array}{l}25 / 30 \mathrm{~kg} \\
\text { wood } \\
\text { crib or } \\
\text { gas } \\
\text { burner } \\
320 \mathrm{~kW} \\
\text { Slightly } \\
\text { increased } \\
\text { for } \\
\text { high rise } \\
\text { buildings }\end{array}$ & $\begin{array}{l}650 \mathrm{~kg} \\
\text { wood } \\
\text { crib/10 kg } \\
\text { Diesel } \\
\text { oil }\end{array}$ & $\begin{array}{l}20 \mathrm{~kg} \\
\text { wood } \\
\text { crib plus } \\
\text { wind } \\
\text { towards } \\
\text { the wall } \\
(2 \mathrm{~m} / \mathrm{s})\end{array}$ & $\begin{array}{l}\text { About } \\
380 \mathrm{~kg} \\
\text { wood } \\
\text { crib } \\
\text { ignited } \\
\text { with } \\
\text { LD fibre } \\
\text { board } \\
\text { soaked in } \\
\text { spirit }\end{array}$ & $\begin{array}{l}25 \mathrm{~kg} \\
\text { wood } \\
\text { crib or } \\
\text { gas } \\
\text { burner, } \\
320 \mathrm{~kW}\end{array}$ & $\begin{array}{l}600 \mathrm{~kg} \\
\text { wood crib } \\
101 \mathrm{mix} \\
\text { with } \\
\text { heptane } \\
\text { and fuel } \\
\text { for } \\
\text { lighting } \\
\text { the crib }\end{array}$ & $\begin{array}{l}601 \\
\text { Heptane }\end{array}$ & $\begin{array}{l}\text { Two gas } \\
\text { burners } \\
900 \mathrm{~kW} \\
\text { in the } \\
\text { room, } \\
400 \mathrm{~kW} \\
\text { in the } \\
\text { window } \\
\text { opening }\end{array}$ & $\begin{array}{l}\text { Propane } \\
\text { gas } \\
\text { burner } \\
120 \mathrm{~g} / \mathrm{s} \\
\text { Liquids } \\
\text { and } \\
\text { wood } \\
\text { (400 kg) } \\
\text { allowed }\end{array}$ \\
\hline \multicolumn{9}{|c|}{ Total height of test rig and configuration } \\
\hline $\begin{array}{l}5.2 \mathrm{~m} \\
\text { min. } \\
\text { Corner, } \\
\text { No } \\
\text { window } \\
\text { opening } \\
\text { above } \\
\text { fire } \\
\text { source }\end{array}$ & $\begin{array}{l}7 \mathrm{~m} \text { min. } \\
\text { No } \\
\text { corner } \\
\text { Second } \\
\text { window } \\
\text { opening } \\
1.3 \mathrm{~m} \\
\text { above } \\
\text { fire } \\
\text { source }\end{array}$ & $\begin{array}{l}2.3 \mathrm{~m} \mathrm{No} \\
\text { corner } \\
\text { No } \\
\text { window } \\
\text { opening } \\
\text { above } \\
\text { fire } \\
\text { source }\end{array}$ & $\begin{array}{l}8 \mathrm{~m} \text { min. } \\
\text { Corner } \\
\text { No } \\
\text { window } \\
\text { opening } \\
\text { above } \\
\text { fire } \\
\text { source }\end{array}$ & $\begin{array}{l}6 \mathrm{~m} \text { min. } \\
\text { Corner } \\
\text { No } \\
\text { window } \\
\text { opening } \\
\text { above } \\
\text { fire } \\
\text { source }\end{array}$ & $\begin{array}{l}5 \mathrm{~m} \\
\text { No corner } \\
\text { One } \\
\text { window } \\
\text { opening } \\
\text { above fire } \\
\text { source }\end{array}$ & $\begin{array}{l}6 \mathrm{~m} \\
\text { No } \\
\text { corner } \\
\text { Two } \\
\text { window } \\
\text { openings } \\
\text { above } \\
\text { fire } \\
\text { source }\end{array}$ & $\begin{array}{l}5.3 \mathrm{~m} \\
\text { No } \\
\text { corner } \\
\text { No } \\
\text { window } \\
\text { opening } \\
\text { above } \\
\text { fire } \\
\text { source }\end{array}$ & $\begin{array}{l}5.7 \mathrm{~m} \\
\text { min. } \\
\text { Corner }\end{array}$ \\
\hline
\end{tabular}

\section{Full scale tests used in different countries}

Many national and also international (ISO) full scale fire tests have been developed, in order to assess the contribution to fire spread of outer façade cladding systems, including insulation systems. Most of them are based on a scenario of a fire from a window opening (caused by a flash-over room fire inside the building) or a fire adjacent to a building. In some cases an inner corner is used, because this represents a more severe situation than a flat wall. Table 1 explains the most important full scale test scenarios used today. Further tests are under development (for example in Japan).

While the test scenarios are quite different regarding fire load as well as height and configuration of the different test rigs, the assessment criteria are in most cases similar:

- Flame spread is used practically in all countries, which have requirements for façade claddings. This is measured by visual observation and temperature measurements.

- Burning parts and droplets are in most cases recorded and used in different ways for assessment.

- Some countries have additional requirements regarding mechanical stability (falling parts and collapse of the cladding system).

- An assessment of the damaged area on and within the different layers of the specimen is often used for assessment of the system.

The regulators group of the European Commission already years ago drafted a mandate, to develop a harmonised European test method with two levels. The idea was to get classifications, which allow 
to cover the legal needs and safety levels used in different EU member states. The CEN mandate was never finalized (so work in CEN did not start) but later on EOTA (European Organisation for Technical Approvals) was asked by the EU commission, to develop such a method for Europe. The reason was that the ETAG 004 for ETICS already included a complete procedure for classification of reaction to fire for ETICS, but allowed an additional national full scale test, which would be different in every member country. So a working group within EOTA started to develop a full scale test method based on the draft mandate, which in the present version contains two levels:

- Level 1, based on the method used in Germany

- Level 2, based on the method used in UK

A first technical report has been finalized in 2012 (approval in 2013) [2] which will be subject to further validation and calibration tests before a final version of the test method can be published.

\section{RELEVANCE OF FOAM PROPERTIES IN END USE CONDITIONS}

For different types of façade insulation system the relevance of the insulation product is not the same.

This can be seen in laboratory and in full scale tests.

\section{The role of EPS foam and factors relevant for safety in ETICS}

For a finished ETICS the relevance of reaction to fire of the insulation foam is not always significant. If the surface layers are very thin, there might be an influence on the performance regarding fire, but if thick and stable covering layers and a stable glass reinforcement layer are used, even non FR EPS can be used, without posing a risk for development and spread of fire in end-use conditions. Of course in all cases where the covering layers open up (or during construction are not fully closed) flame retarded EPS will contribute to safety.

By full scale tests, first performed in Germany, it could be shown, that special provisions need to be taken, to deal with the melting and shrinking behaviour of EPS. Even if protective covering layers are in place, this is important. The reason is, that under the impact of heat, the EPS behind the outer covering will shrink and melt. Under the impact of the fire the outer layers might be damaged, or open at the lintels, and then fast fire spread in the void can happen. In order to prevent this, different provisions have been developed:

- Barriers above (and in some cases around openings like windows and doors) of non-melting material (mineral wool or other products, which remain stable in case of a fire)

- Horizontal barriers around the building between different floors

- Good quality of mortar and reinforcement layers.

\section{Ventilated façades}

For ventilated façades the important parameters are:

- Design and construction: Ventilation gaps, which are not closed at the upper, lower and side edges (and at openings like windows), and without fire barriers between floors, will always lead to fire spread within the ventilation gap, even if non-combustible cladding and insulation are used.

- Outer cladding: if the outer cladding is combustible (as for example in the recent fires in Dijon, Polat Tower in Turkey and in Grosny) the combination of these combustible claddings and the ventilation gap will lead to fast fire spread.

- Insulation: Combustible insulation (as for example EPS, even if it is fire retarded) may significantly increase fire spread. Safe application is only possible, if sufficient, sophisticated fire barriers (for example including intumescent products) are installed. 

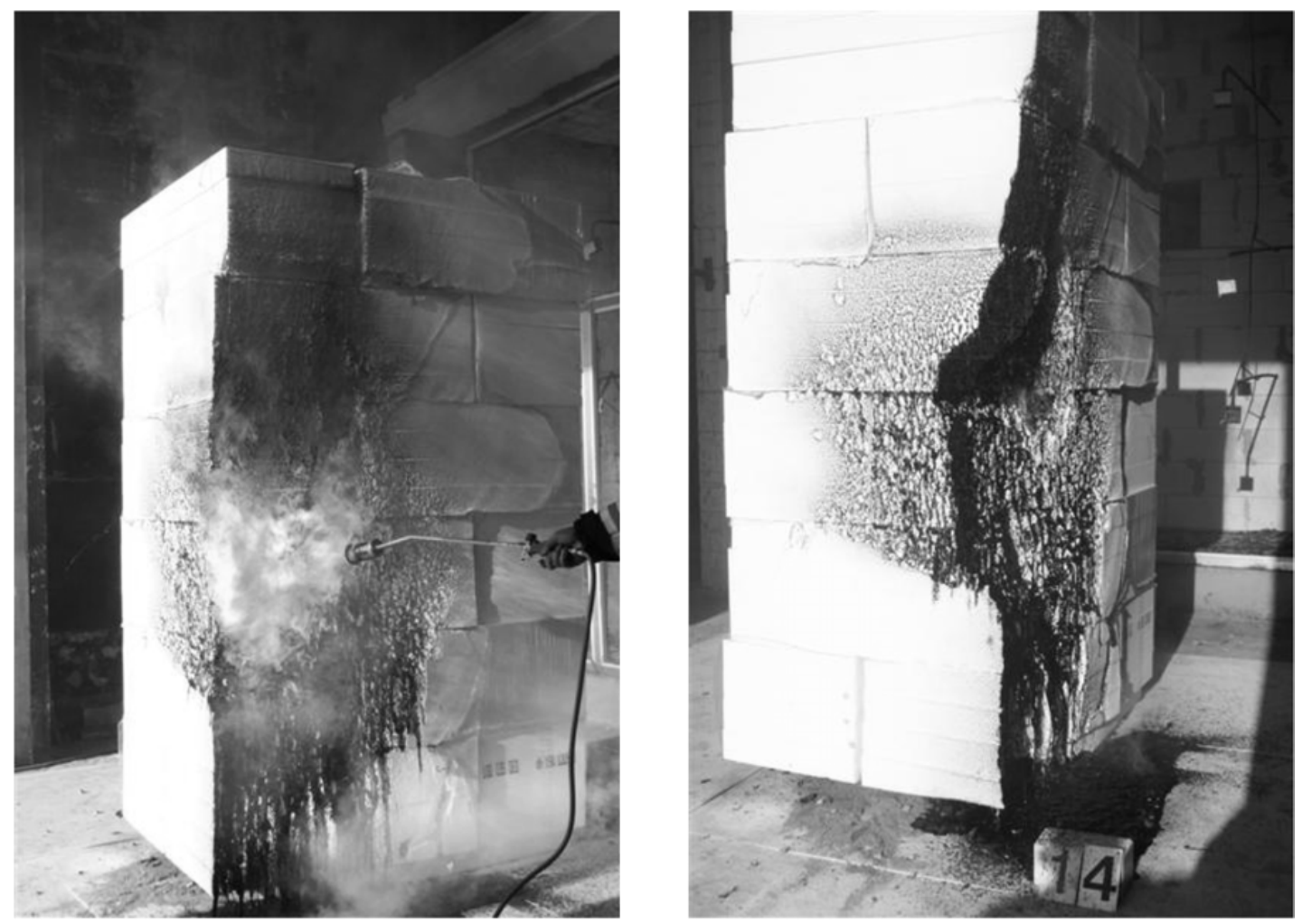

Figure 1. Flame retarded (class E) EPS during and after flame impingement with gas burner.

\section{FIRE SAFETY DURING STORAGE, TRANSPORT AND CONSTRUCTION}

After some fires incidents (China, Germany), a discussion has been started about fire safety during construction when EPS is used. IF non FR EPS is used, there is indeed a high risk, that stored EPS or EPS on a façade, which is not yet fully covered with the final outer layers, will be ignited and lead to rapid and dangerous spread of fire.

After a fire incident in Germany (Frankfurt, 2012) a number of tests was performed at MPA Leipzig, which show, that the flame retarded EPS will not be ignited by smaller or medium ignition sources, as they may be expected on a construction site. The following ignition sources were not sufficient to ignite the stored EPS:

- cigarettes

- welding/cutting sparks

- burning paper

- pyrotechnic articles, like Bengal lights and small skyrockets

- Molotov cocktails

- gas burner.

Similar fire sources were used on EPS glued to a wall, but not yet covered by the outer reinforcement and covering layers of the ETICS.

In all cases it could be shown, that flame retarded EPS will not be ignited by usual fire sources accidentally or by arson. Very special configurations and/or significant energy input will be necessary to start a fire of flame retarded EPS during transport, storage or installation. But if that happens of course, 

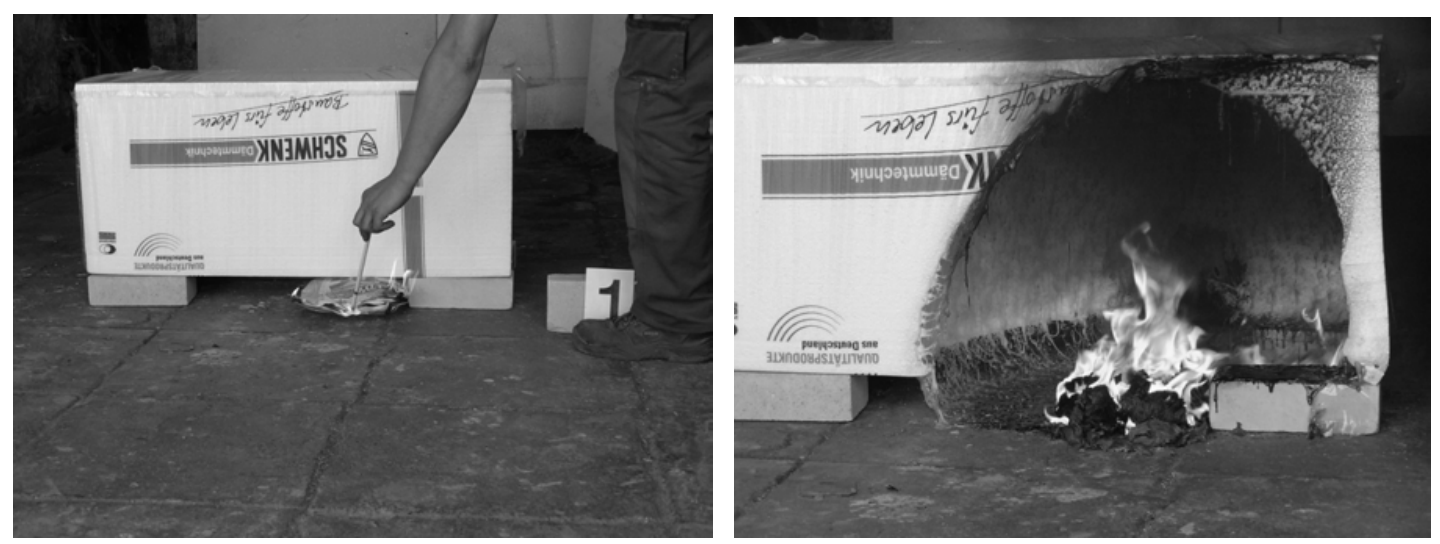

Figure 2. Paper cushion ignited below stored EPS - Melting but no continuous burning of EPS.

like for all other combustible construction products (wood, bituminous roofing felts etc.) the result could be a major fire.

For non flame retarded EPS the situation is completely different. Even small ignition sources like a cigarette or welding sparks might ignite stored material and lead to a major fire. So this product, which in some end-use applications, like behind plasterboard or on the outside of a building behind a very thick layer of mortar, will not lead to additional risks in case of a fire, has to be handled especially careful during transport, storage and ongoing construction. This is why a number of countries allow only flame retarded (class E) EPS for construction, independent from the end-use situation.

It will always be important to respect basic safety rules, which apply wherever combustible products are used (which might be EPS, as well as wood, roofing felts, glues, solvents etc.). These safety rules include the limitation of storage of combustible goods near parts of the building, especially where combustible products are already applied on a facade, but the complete system is not yet in place (like insulation boards without covering).

\section{RELEVANCE OF FAÇADE FIRES AND OF FIRES OF ETICS WITH EPS}

Many fatal fires have occurred in the past. A lot of buildings were built mainly of wood, heating was done with open fires and the technical equipment of fire fighters was not as good as today. This is why whole cities have been destroyed by raging fires (for example the great fire in London in 1666 and the two fires in New York 1776 and 1845).

Today the situation has changed significantly. On the one hand materials used for construction have changed. For building structures wood has often been replaced by stone, concrete or steel structures or it is protected by fire retardant coatings or extra protection layers. Fire brigades have better technical equipment and can in most places reach fires faster than in the past. The increasing use of smoke detectors is a good tool to reduce the probability of development of a fire into a situation, where it is difficult to extinguish it. Legislation regarding fire safe construction is in place and enforced in most countries and is permanently under revision.

On the other hand there is an increased fire load inside residential buildings, because more furniture and internal decoration is used than in the past. A question which has been discussed more and more in the last years is, whether the increasing use of thermal insulation systems on the outside of façades could have a negative impact regarding fire safety.

The discussion of the role of ETICS with combustible insulation for fire safety is especially difficult, because only a limited amount of statistical data is available. But using the available information, a 


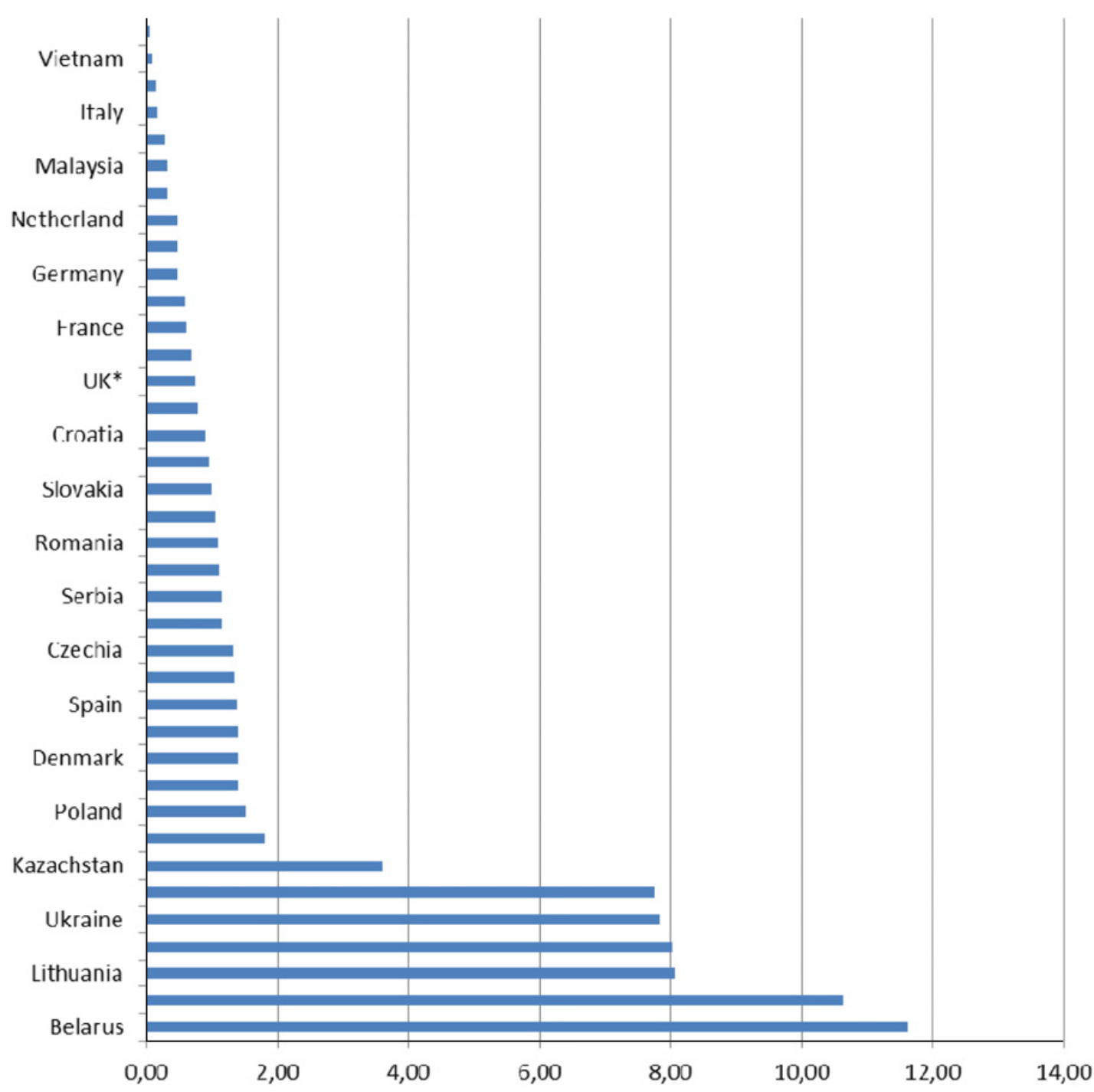

Figure 3. Average values between 2006 and 2010 of fire deaths/100000 inhabitants [1].

context between the use of combustible insulation and serious fires cannot be deduced from the existing data. Data from the CTIF (International Association of Fire and Rescue Services) Report no 17, 2012 [3] (see figure 3) clearly show, that countries where ETICS with combustible insulation (mainly EPS) are widely used since more than 50 years (like Germany and Austria) have a relatively low number of fire fatalities per 100000 inhabitants, compared to countries, where ETICS are practically not used or countries, where insulation in most cases is done with non-combustible products (i.e. Denmark).

Another interesting information is the evaluation of the number of fire deaths in Germany. In spite of the wide spread application of ETICS with combustible insulation (in Germany since 1994 every year an average of 40 million square meters have been installed, with about $80 \%$ EPS as insulation material), in Germany in 2012 from all fatalities reported on Feuerwehr.de [4] (website of German fire brigades) only in one case people were killed from a fire which did not start in their own apartment or family home. This was a fire in Metzingen in a garage below some houses. The smoke spread upwards in the 
building and two people died and 17 were injured. So in a country, where a lot of ETICS with EPS insulation are in place, the most important reason for fire fatalities are fires in homes, caused by candles, cooking and other small fire sources inside these homes and not fire spread along façades.

After a fire on a construction site in Germany (Frankfurt Adickesallee, May 2012) fire brigades started to worry, whether there is an increasing risk that dangerous fires on façades will happen, because of ETICS insulated with EPS. This was discussed in the regulatory group, which is responsible for fire codes in Germany (Bauministerkonferenz). It was concluded, that a working group including fire brigades should collect data about fires during the last years, where ETICS were involved, and analyze, whether there is a need for different and stricter regulations.

In March 2013 the first results of this analysis were published. 18 fire incidents have been analysed, which had been reported from all German fire brigades, after a request to send all existing information about façade fires with ETICS with EPS insulation. This shows already that in Germany, where millions of square meters have been applied during the last years, these fires do not have a relevant percentage only in 2012 in Germany on the website of the fire brigades Feuerwehr.de more than 2200 fire incidents were reported (this is even not complete, because fire brigades report on a voluntary basis).

The result of the analysis of this up-mentioned working group was, that in case of a fire leaking out of a window, after flashover in a room, the rules for approval of ETICS applied in Germany are good enough and safety is satisfactory. To make sure, that also fires starting from the outside of the building (like burning waste paper containers) are covered, additional tests will be done soon. In addition it is planned to discuss additional safety requirements during construction, because in this case the combustible insulation is not yet covered by reinforcement and rendering layers. Also the risk of start of a fire is relatively high, because often combustible products, including pallets and packaging materials are almost always stored on construction sites and hot works will be done. General guidelines for fire safety during construction have already been developed in several countries (for example by insurers), but not many regulatory requirements are yet in place.

\section{SUMMARY}

EPS is a combustible product. There are flame retarded and non flame retarded products. For construction purposes it is always recommended to use flame retarded EPS, even if in end-use it is covered by a solid protective outer layer, because during transport, storage and construction the reaction to fire of the product alone is important for safety.

For ETICS classification of reaction to fire is complex. The small burner test is a good tool, to differentiate between flame retarded (class E) and non flame retarded EPS. All other layers of an ETICS can also be assessed with this method. For the complete system higher classes can be achieved, if an SBI test is passed. For this test the quality of the outer mortar and reinforcement layers of the ETICS is most important.

In addition experience is available, that the complete assessment of fire safety of ETICS can only be done in full scale tests. Here again different factors are important

- Quality and stability of the covering layers

- Additional details like fire barriers

- Only if the outer layers and fire barriers do not efficiently protect the insulation layer, there is an influence of the quality of the EPS. But in the case of a failure of the covering layers, even with well flame retarded EPS, there will be a significant contribution to fire spread. But of course this will then be worse with non FR EPS than with flame retarded EPS.

Full scale tests have led to development of additional fire safety measures for ETICS with EPS, taking into account the special fire safety issues due to the melting behaviour of EPS. These are normally fire barriers above openings or around the building between the windows. Experience especially from Germany, where ETICS have been applied for many years, shows, that these provisions are efficient for low and medium sized buildings. For high rise buildings and buildings with exceptional risk, for 


\section{MATEC Web of Conferences}

example in UK additional requirements (based on full scale test and not on laboratory tests of the insulation product) have been developed, which are deemed to satisfy the safety requirements These also allow the use of ETICS with EPS, but in addition to the use of fire barriers a very high quality of the rendering and reinforcement layer is necessary.

\section{References}

[1] ETAG 004 Guideline for European Technical Approval of External Thermal Insulation Composite Systems with Rendering

[2] Technical Report, Large scale fire performance testing of external wall cladding systems, January $11^{\text {th }}, 2013$, EOTA PT 4 task group

[3] Numbers from CTIF Report no 17, 2012

[4] www.feuerwehr.de Einsatzberichte 